\title{
Development, Quality Evaluation and Shelf Life Studies of Probiotic Beverages using Whey and Aloe vera Juice
}

Sasi Kumar $\mathbf{R}^{*}$

Department of Agri-Business Management and Food Technology, North-Eastern Hill University, NEHU Tura Campus, Chandmari, Meghalaya, India

\begin{abstract}
The investigation was aimed to develop a probiotic beverage using whey and Aloe vera juice. Bifidobacterium bifidus (BB) was used as the probiotic organism, the level of whey and Aloe vera juice, addition of probiotic inoculums and fermentation time were optimized on the basis of sensory quality evaluation. The blend ratio 70:30 of whey and Aloe vera juice and whey fermented for 9 hrs using inoculums $1 \%$ BB resulted with highest sensory scores for overall acceptability. The developed probiotic beverage could be recommended for the large scale production at industrial level.
\end{abstract}

Keywords: Whey; Probiotic beverage; Aloe vera whey beverage; Sensory quality; Shelf life studies

\section{Introduction}

Milk whey drink can replace much of the lost organic and inorganic to the extracellular fluid. Whey, which is so rapidly assimilable, forms an ideal metabolic substrate. Whey is one of the highly nutritious byproducts obtained from the dairy industry producing cheese, chhanna and paneer. It constitutes almost 45-50 percent of total milk solids, 70 percent of milk sugar mainly lactose, 20 percent of milk proteins, 70 90 percent of milk minerals and almost all the water soluble vitamins originally present in milk $[1,2]$. It resulted into unravelling the secrets of whey proteins and other components and established a sound basis for their nutritional and functional value [3]. Several authors have investigated the possibility of utilizing the milk whey in the fruit beverage preparation [4]. The manufacture of whey based beverage requires the mixing of appropriate fruit juices and minimally processed whey with selection of suitable stabilizers and acidulants to develop acceptable whey based fruit beverages [5]

The functional beverages covers probiotic beverages, dairy drinks, drinking yoghurts, functional and functionally fortified soft drinks, juices, energy drinks, sports drinks, functional waters and readyto-drink tea. The global functional beverages market drives due to the growth in health and wellness concerns increase in disposable incomes, consumer awareness, introduction of new flavoured products meeting various nutritional and health requirements, obesity concerns, aging population and changing lifestyles [6]. Energy drinks is the fastest growing segment in functional drinks market followed by functional dairy products and nutraceutical drinks.

Functional Drinks Reassessing future potential, determining consumer targets, and delivering credible products provides a comprehensive overview of the functional drink landscape, analyzing the regulatory and consumer drivers to identify the best opportunities and strategies [7]. The global regulatory environment is examined and key hubs for innovation are highlighted. The report investigates the opportunities that the functional drinks market provides for beverage manufacturers as well as the challenges that diversification into functional beverages presents.

Fresh Aloe vera leaves used to obtain two components, firstly bitter yellow latex from peripheral bundle sheath of aloe, called Aloe vera sap and a mucilaginous gel from parenchymatous tissue. The interest and use of gel has increased dramatically in the field of health care and cosmetics [8]. It can be utilized as a valuable ingredient for food application due to its biological activities and functional properties [9]. Aloe vera has a bitter taste which can be unpleasant in raw state and its palatability could be enhanced with addition of some other fruit juices.

The conception of probiotic came into focus in early 1900's but the term "probiotic" was suggested by Lilly and Stillwell. Probiotic cultures are live microbial food ingredients that are beneficial for human health [10], which includes improvement of intestinal microbial balance which results in the inhibition of bacterial pathogens, reducing the risk of colon cancer, improving the immune system, lowering serum cholesterol levels [11], alleviation of lactose intolerance and nutritional enhancement [12].

The probiotic culture like Bifidobacterium bifidum specific organism used as a probiotic and its health promoting effects $[13,14]$ and in recent years, which has been considered important bacteria for human health; the main probiotic effects attributed to these bacteria include: improvement in lactose utilisation, prevention of diarrhoea, colon cancer, hypercholesterolemia, improvement of vitamin synthesis and calcium absorption [15], development of longer villi and significantly production of substances of low molecular mass with antimicrobial activity [16].

The manufacture of whey-based beverages requires the mixing of appropriate fruit juices and minimally processed whey with selection of suitable stabilizers and acidulants to develop acceptable whey based fruit beverages [17]. Recently, the key growth sector in utilization of whey has been probiotic drinks and their role in fermentation processes, some probiotic lactic acid bacteria have been studied as dietary sources of live microorganisms destined to promote a positive impact in the host by improving the properties of the indigenous beneficial microflora [18]. Based on these facts, the present investigation was conducted to develop a probiotic beverage using whey and Aloe vera juice and to study its storage stability.

*Corresonding author: Sasi Kumar R, Department of Agri-Business Management and Food Technology, North-Eastern Hill University, NEHU Tura Campus, Chandmari-794002, Meghalaya, India, E-mail: sashibiofood@yahoo.co.in

Received June 15, 2015; Accepted July 07, 2015; Published July 14, 2015

Citation: Sasi Kumar R (2015) Development, Quality Evaluation and Shelf Life Studies of Probiotic Beverages using Whey and Aloe vera Juice. J Food Process Technol 6: 486. doi:10.4172/2157-7110.1000486

Copyright: ( 2015 Sasi Kumar R. This is an open-access article distributed unde the terms of the Creative Commons Attribution License, which permits unrestricted use, distribution, and reproduction in any medium, provided the original author and source are credited. 


\section{Materials and Methods}

\section{Sample preparation}

Skim milk was heated in a stainless steel vessel to $95^{\circ} \mathrm{C}$ followed by cooling to $70^{\circ} \mathrm{C}$. The hot milk was acidified by adding $2 \%$ of citric acid solution followed by continuous stirring which resulted in the complete coagulation of the milk protein (casein). The liquid (whey) was filtered using muslin cloth. The prepared whey was heated to $85^{\circ} \mathrm{C}$ before blending with Aloe vera juice.

The freeze dried probiotic culture Bifidobacterium bifidus NCDC 255 was obtained from National Dairy Research Institute, Karnal, India. Culture was cultivated in $10 \%$ non-fat dry milk, autoclaved at $115^{\circ} \mathrm{C}$ for $15 \mathrm{~min}$, inoculated under sterile conditions, incubated at 42 $\pm 1^{\circ} \mathrm{C}$ and kept in refrigerator at $4 \pm 1^{\circ} \mathrm{C}$ until used.

Aloe vera juice: Aloe vera juice, chemical composition of juices depends majorly upon the method of juice extraction [19]. Aloe vera juice was extracted using cold extraction method and processed into juice as per the method reported by Williams [20]. Freshly harvested Aloe vera leaves were dipped into $500 \mathrm{ppm}$ of potassium meta bisulphite (KMS) solution and washed thoroughly with tap water and kept for flash cooling to $5^{\circ} \mathrm{C}$ for juice stabilization. Further leaves were cut vertically into two half and juice was separated using stainless steel knife, it was allowed to settle for $12 \mathrm{hrs}$ and then homogenized using mixer grinder and enzymatically treated with $1 \%$ pectolytic enzyme at $50^{\circ} \mathrm{C}$ for 20 minutes. Then it was filtered and $\mathrm{pH}$ was adjusted to 3.0 by adding citric acid and ascorbic acid to control browning while high heat treatment. Further it was dearated, pasteurized, flash cooled and stored. During the pasteurization pectolytic enzyme was inactivated. The obtained juice was stored refrigerated temperature until further use.

Probiotic beverage process: The combination of whey and Aloe vera juice were optimized with different blends ratio, such that sample A (65wy:35Av), sample B (70wy:30Av), sample C (75wy:25Av) and sample D (80wy:20Av). The beverage incubation period was optimized by inoculating $1 \%$ of probiotic culture (Bifidobacterium bifidus) to whey and sample with addition of sugar level $15 \%$ and fermented for $5,9,13,17$ and 21 and $24 \mathrm{hrs}$ then the beverages were evaluated for sensory characteristics, total viable count, $\mathrm{pH}$, titratable acidity, storage stability and shelf life studies carried out for sample with different blend and fermented periods.

\section{Analytical methods}

Bio-chemical and microbiological methods: Total soluble solid was measured using a hand refractometer of $0-32^{\circ} \mathrm{B}$ (ERMA make). The $\mathrm{pH}$ of the beverages was determined using the digital $\mathrm{pH}$ meter (Model No. 5633, Electronics Corporation of India Ltd., Hyderabad). Titratable acidity was determined according to the AOAC [21] method. Viable counts in the samples were determined according to A.P.H.A. [22] procedure using lactic agar [23].

\section{Statistical analysis}

Statistical procedures as described by Snedecor and Cochran [24] were used to analyze the data for the interpretation of results. Mean, standard deviation and analysis of variance (ANOVA) were used to describe the results.

\section{Sensory quality evaluation}

The beverage samples were evaluated as described by Larmond [25] for their sensory characteristics namely colour and appearance, taste and flavour, body or consistency and overall acceptability by a trained panels. The panellists were asked to record their observations on the sensory sheet based on a 9 points hedonic scale ( 9 and 1 points showing like extremely and dislike extremely).

\section{Results and Discussion}

\section{Optimization of whey and Aloe vera juice blend ratio levels for beverage preparation}

Whey and Aloe vera juice were blended in five different proportions i.e. A (65wy:35Av), B (70wy:30Av), C (75wy:25Av) and D (80wy:20Av) and evaluated for sensory attributes namely colour and appearance, consistency, flavour and overall acceptability. The sample B was highest score for flavour, consistency, colour and appearance to beverage preparation. The mean scores of this blend for colour and appearance, consistency, flavour and overall acceptability were 7.93, 7.81, 8.37 and 8.93 respectively. Therefore, sample $B$ was chosen for the further investigation and differed significantly $(\mathrm{P}<0.05)$ and rated best among others samples.

\section{Optimization of growth conditions for Bifidobacterium bifidus $(\mathrm{BB})$ in beverage}

Whey and sample B were supplemented with $15 \%$ sucrose and fermented for different time intervals. Variations in fermentation time were studied in terms of overall acceptability, $\mathrm{pH}$, titratable acidity and total viable counts of the beverage. The effect of Bifidobacterium bifidus (BB) on sensory attributes of whey with or without addition of Aloe vera juice during fermentation has been shown in Table 1. Colour and appearance of the beverage was significantly $(\mathrm{P} \leq 0.05)$ affected by the incubation period. The mean scores for colour and appearance ranged from 7.56 to 5.87 for whey. The mean score was highest (7.56) for whey fermented for $9 \mathrm{hrs}$. The sensory scores for consistency reduced significantly $(\mathrm{P} \leq 0.05)$ with increase in fermentation time for both whey and sample $B$.

The sensory score for consistency of fermented whey ranged from 7.55 to 5.97 but the sensory scores for consistency of sample B was ranged from 8.12 to 6.15 . The sensory scores for flavour ranged from 7.21 to 5.17 for whey fermented alone and from 7.91 to 6.97 for sample B. The mean score for flavour decreased significantly with increasing fermentation time irrespective of the medium. The mean score for overall acceptability ranged from 7.31 to 5.80 for whey and 8.10 to 6.34 for sample B. Highest score for overall acceptability was seen in case of sample B fermented for $9 \mathrm{hrs}$.

\section{Enumeration of total viable counts}

The viable counts were assessed after 5, 9, 13, 17, 21 and $24 \mathrm{hrs}$ of incubation at $37^{\circ} \mathrm{C}$. It was observed that whey gave higher viable counts $\left(9.54 \times 10^{8} \mathrm{cfu} / \mathrm{ml}\right)$ up to $24 \mathrm{hrs}$ of fermentation. But after $24 \mathrm{hrs}$, the sample $B$ fermented alone, gave higher viable counts ranging from $3.35 \times 10^{7}$ to $8.10 \times 10^{8} \mathrm{cfu} / \mathrm{ml}$. Both whey and sample B attained a total viable count of more than $5.0 \times 10^{8} \mathrm{cfu} / \mathrm{ml}$ within $13 \mathrm{hrs}$ of fermentation (Table 2). The total viable count increased significantly with increase in fermentation time from 5 to $24 \mathrm{hrs}$. The total viable count for whey ranged from $2.23 \times 10^{7}$ to $9.54 \times 10^{8} \mathrm{cfu} / \mathrm{ml}$. Sample B showed the stable increase total viable count with increasing fermentation time as controlled way but the whey alone showed uncontrolled fermentation with increasing fermentation time.

\section{Effect of probiotic on $\mathrm{pH}$ and titratable acidity}

Table 3 shows the effect of incubation period on the $\mathrm{pH}$ of whey and sample B, $\mathrm{pH}$ of the samples (whey and sample B) reduced significantly 
Citation: Sasi Kumar R (2015) Development, Quality Evaluation and Shelf Life Studies of Probiotic Beverages using Whey and Aloe vera Juice. J Food Process Technol 6: 486. doi:10.4172/2157-7110.1000486

Page 3 of 5

\begin{tabular}{|c|c|c|c|c|c|}
\hline \multirow{2}{*}{ Sr.No } & \multirow{2}{*}{ Name of the sample } & \multicolumn{4}{|l|}{ Sensory Scores * } \\
\hline & & Colour and Appearance & Consistency & Flavour & Overall Acceptability \\
\hline 1 & Sample A & $7.15^{\mathrm{B}}$ & $7.21^{\mathrm{AB}}$ & $7.38^{\mathrm{B}}$ & $7.23^{\mathrm{B}}$ \\
\hline 2 & Sample B & $7.91^{\mathrm{A}}$ & $7.86^{\mathrm{A}}$ & $8.21^{\mathrm{A}}$ & $8.54^{\mathrm{A}}$ \\
\hline 3 & Sample C & $6.95^{\mathrm{B}}$ & $6.81^{\mathrm{B}}$ & $7.11^{\mathrm{C}}$ & $7.12^{\mathrm{C}}$ \\
\hline 4 & Sample D & $6.72^{\mathrm{C}}$ & $6.68^{\mathrm{C}}$ & $6.92^{\mathrm{D}}$ & $6.96^{\mathrm{D}}$ \\
\hline 5 & S.E.M & 0.189 & 0.186 & 0.153 & 0.123 \\
\hline 6 & CD at $5 \%$ & 0.533 & 0.525 & 0.452 & 0.361 \\
\hline
\end{tabular}

Sample A (65wy:35Av), Sample B (70wy:30Av), Sample C (75wy:25Av) and Sample D (80wy:20Av)

*Average of four trials

* Means by different letters (A, B, C, D) as superscripts in a column differ significantly at $5 \%$ level

Table 1: Effect of different blends of whey and Aloe vera juice on the sensory characteristics of the beverage.

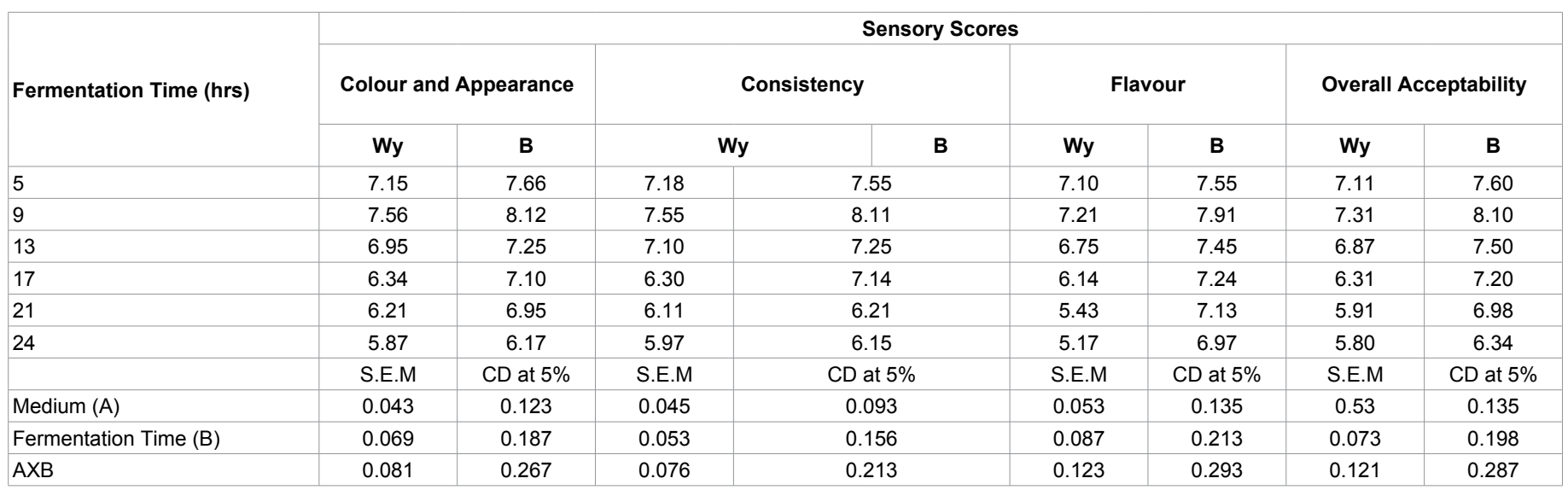

*Wy-Whey, Sample B (70wy:30Av)

Table 2: Effect of Bifidobacteriumbifidus(BB) on sensory characteristics of whey and sample $\mathrm{B}$ at $37 \pm 1^{\circ} \mathrm{C}$

$(\mathrm{P}<0.05)$ with increasing fermentation time. The mean value of $\mathrm{pH}$ obtained in case of whey fermented alone ranged from 4.85 to 3.43. The mean value of $\mathrm{pH}$ obtained in case of sample B ranged from 4.65 to 3.44. Higher viable counts during the last stage of fermentation (24 hrs) resulted in comparative lowering of $\mathrm{pH}$ for whey and sample $\mathrm{B}$. The sample B showed gradual decrease $\mathrm{pH}$ value with increase of fermentation time because of controlled fermentation during entire $24 \mathrm{hrs}$, but whey alone showed uncontrolled fermentation process for $24 \mathrm{hrs}$.

Table 3 shows the effect of incubation period on the titratable acidity of whey and sample $\mathrm{B}$. Titratable acidity increased significantly $(\mathrm{P} \leq$ $0.05)$ with increasing fermentation time irrespective of the medium. The mean values obtained for whey ranged from 0.390 to 1.293 . The mean values obtained for sample B ranged from 0.453 to 0.945 . Sample B showed balanced titratable acidity from 5 to 24 hrs of fermentation process, because of Aloe vera juice blend with whey, whereas there was a significant increase in the titratable acidity with respect of increasing fermentation time ( 5 to $24 \mathrm{hrs}$ ) for whey and sample B. The commercial probiotic beverage should possess a minimum viable count of $4.11 \times 10^{7} \mathrm{cfu} / \mathrm{ml}$ with optimum fermentation time $(9 \mathrm{hrs}) \mathrm{cfu} / \mathrm{ml}$ and should also have an acceptable flavour. The commercial probiotic beverage should possess a minimum viable count of $106 \mathrm{cfu} / \mathrm{ml} \mathrm{[26]} \mathrm{and}$ should also have an acceptable flavour.

Keeping in view these aspects, experiments were carried out to appraise the suitability of whey with or without the addition of Aloe vera juice as a growth medium for Bifidobacterium bifidus (BB) for the preparation of probiotic beverage. It was observed that sample B for 9 hrs gave the highest scores for overall acceptability (8.10) as compared to whey fermented alone (7.31). The scores for overall acceptability gradually declined with increasing fermentation time irrespective of the medium. Table 4 shows that the $\mathrm{pH}$ and titratable acidity affects colour and appearance, consistency, flavour profile and overall accepbility of a beverage. In the present study, it was observed that sample B having a $\mathrm{pH}$ of 4.50 and titratable acidity of $0.525 \%$ gave the best colour and appearance, consistency, flavour profile and overall acceptability to the probiotic beverage. These observations exhibited an acceptable beverage by fermenting a blend of whey and Aloe vera juice (70:30) that is sample B for a period of $9 \mathrm{hrs}$. The prepared product had desired health benefits due to the probiotic organisms.

\section{Storage studies of probiotic beverage}

The changes in sensory attributes on storage studies of the probiotic beverage have been shown in Table 4 for refrigerated and ambient storage temperatures. The whey and Aloe vera based probiotic beverage did not show sensory differences for the first 15 days at refrigerated storage. But after the 15 days, difference was perceived in colour and appearance and flavour. According to a consensus made with the panelists during sensory evaluation, it was determined that the main descriptors that characterized the product were acidity and sweetness, with acidity being the attribute responsible for the sensory difference perceived by the panelists. Even though a slight acidification was detected by the sensory panels and agreed that the beverage was acceptable for a period of 30 days at $4^{\circ} \mathrm{C} \pm 1^{\circ} \mathrm{C}$ and 6 days at $35^{\circ} \mathrm{C} \pm 1^{\circ} \mathrm{C}$.

The $\mathrm{pH}$ of the fresh beverage prepared from blend of whey and Aloe vera juice fermented for $5 \mathrm{hr}$ was 4.40 . The $\mathrm{pH}$ of the samples gradually declined during 30 days at refrigerated storage. The $\mathrm{pH}$ ranged from 4.40 to 4.00 after 30 days of storage. During storage of the samples at ambient temperature, $\mathrm{pH}$ lowered significantly $(\mathrm{P} \leq 0.05)$ after 6 days. The initial acidity of the fermented beverage prepared 
Citation: Sasi Kumar R (2015) Development, Quality Evaluation and Shelf Life Studies of Probiotic Beverages using Whey and Aloe vera Juice. J Food Process Technol 6: 486. doi:10.4172/2157-7110.1000486

Page 4 of 5

\begin{tabular}{|l|c|c|c|}
\hline \multirow{2}{*}{ Sr.No } & $\begin{array}{c}\text { Fermentation Time } \\
\text { (hrs) @ } \mathbf{3 7}^{\circ} \mathbf{C}\end{array}$ & Whey (cfu/ml) & \multicolumn{2}{|c|}{ Medium } \\
\cline { 2 - 4 } & 5 & $2.23 \times 10^{7}$ & $3.35 \times 10^{7}$ \\
\hline 2 & 9 & $3.23 \times 10^{7}$ & $4.11 \times 10^{7}$ \\
\hline 3 & 13 & $5.90 \times 10^{8}$ & $5.18 \times 10^{8}$ \\
\hline 4 & 17 & $8.23 \times 10^{8}$ & $6.88 \times 10^{8}$ \\
\hline 5 & 21 & $9.10 \times 10^{8}$ & $7.64 \times 10^{8}$ \\
\hline 6 & 24 & $9.54 \times 10^{8}$ & $8.10 \times 10^{8}$ \\
\hline & & Medium (A) & Fermentation Time (B) \\
\hline & SEM & $3.11 \times 10^{4}$ & $4.31 \times 10^{4}$ \\
\hline
\end{tabular}

Table 3: Effect of fermentation period on the total viable count of whey with and without Aloe vera juice.

\begin{tabular}{|c|c|c|c|c|c|}
\hline \multirow{3}{*}{ Sr.No } & \multirow{3}{*}{ Fermentation Time } & \multicolumn{4}{|c|}{ Medium } \\
\hline & & \multicolumn{2}{|c|}{ Whey } & \multicolumn{2}{|c|}{ Sample B } \\
\hline & & $\mathrm{pH}$ & T.A \% & $\mathrm{pH}$ & T.A \% \\
\hline 1 & 5 & 4.85 & 0.390 & 4.65 & 0.453 \\
\hline 2 & 9 & 4.55 & 0.496 & 4.50 & 0.525 \\
\hline 3 & 13 & 4.13 & 0.915 & 4.25 & 0.680 \\
\hline 4 & 17 & 3.98 & 1.023 & 4.00 & 0.796 \\
\hline 5 & 21 & 3.60 & 1.165 & 3.87 & 0.815 \\
\hline \multirow[t]{4}{*}{6} & 24 & 3.43 & 1.293 & 3.44 & \\
\hline & & \multicolumn{2}{|c|}{ Medium (A) } & Fermentation Time (B) & $A X B$ \\
\hline & SEM & \multicolumn{2}{|c|}{0.0250} & 0.00051 & 0.0716 \\
\hline & CD at $5 \%$ & \multicolumn{2}{|c|}{0.0564} & 0.0219 & 0.0303 \\
\hline
\end{tabular}

* Incubation temperature: $37 \pm 1^{\circ} \mathrm{C}$.

Table 4: Effect of fermentation period on the $\mathrm{pH}$ and titratable acidity of whey with and without Aloe vera juice.

\begin{tabular}{|c|c|c|c|c|c|c|c|c|}
\hline Sr.No & $\begin{array}{l}\text { S.P (d) } \\
\text { at } 4^{\circ} \mathrm{C}\end{array}$ & $\mathrm{pH}$ & T.A. (\%) La & TPC (cfu) & S.P (d) at $35^{\circ} \mathrm{C}$ & $\mathrm{pH}$ & T.A (\%) La & TPC (cfu) \\
\hline 1 & 0 & 4.40 & 0.553 & $3.5 \times 10^{7}$ & 0 & 4.40 & 0.553 & $3.5 \times 10^{7}$ \\
\hline 2 & 5 & 4.39 & 0.551 & $3.1 \times 10^{7}$ & 1 & 4.35 & 0.610 & $5.2 \times 10^{8}$ \\
\hline 3 & 10 & 4.38 & 0.563 & $2.7 \times 10^{7}$ & 2 & 4.30 & 0.723 & $8.7 \times 10^{8}$ \\
\hline 4 & 15 & 4.37 & 0.580 & $2.7 \times 10^{7}$ & 3 & 4.26 & 0.793 & $6.1 \times 10^{7}$ \\
\hline 5 & 20 & 4.35 & 0.594 & $2.1 \times 10^{7}$ & 4 & 4.10 & 0.843 & $4.4 \times 10^{7}$ \\
\hline 6 & 25 & 4.35 & 0.610 & $1.7 \times 10^{7}$ & 5 & 4.00 & 0.910 & $3.1 \times 10^{7}$ \\
\hline 7 & 30 & 4.00 & 0.870 & $1.3 \times 10^{7}$ & 6 & 3.83 & 1.120 & $2.3 \times 10^{7}$ \\
\hline
\end{tabular}

Table 5: Changes in $\mathrm{pH}$, total viable count and titratable acidity of the sample B probiotic beverage during storage.

\begin{tabular}{|c|c|c|c|c|c|c|c|c|c|}
\hline $\begin{array}{l}\mathrm{SP}(\mathrm{d}) \\
\text { at } 4^{\circ} \mathrm{C}\end{array}$ & $C$ and $A$ & Cons & Flav & OAA & $\mathrm{SP}(\mathrm{d})$ at $35^{\circ} \mathrm{C}$ & $C$ and $A$ & Cons & Flav & OAA \\
\hline 0 & $8.53^{a}$ & $8.65^{a}$ & $8.74^{a}$ & $8.63^{a}$ & 0 & $8.58^{a}$ & $8.60^{\mathrm{a}}$ & $8.73^{a}$ & $8.67^{a}$ \\
\hline 5 & $8.51^{\mathrm{a}}$ & $8.64^{a}$ & $8.73^{a}$ & $8.63^{a}$ & 1 & $8.45^{a}$ & $8.50^{\mathrm{a}}$ & $8.68^{a}$ & $8.58^{\mathrm{a}}$ \\
\hline 10 & $8.36^{a}$ & $8.40^{b, c}$ & $8.51^{a}$ & $8.43^{a}$ & 2 & $8.00^{a}$ & $8.15^{a, b}$ & $8.14^{b}$ & $8.15^{\mathrm{a}}$ \\
\hline 15 & $8.11^{\mathrm{a}}$ & $8.00^{b, c}$ & $7.91^{\mathrm{b}}$ & $8.13^{b, c}$ & 3 & $7.83^{\mathrm{b}}$ & $7.95^{\mathrm{b}}$ & $7.75^{\mathrm{c}}$ & $7.88^{b}$ \\
\hline 20 & $7.93^{b}$ & $7.95^{\mathrm{c}}$ & $7.74^{c}$ & $7.73^{c}$ & 4 & $7.13^{c}$ & $7.15^{\mathrm{c}}$ & $7.00^{d}$ & $7.14^{c}$ \\
\hline 25 & $7.20^{\mathrm{c}}$ & $7.15^{\mathrm{d}, \mathrm{e}}$ & $7.00^{d}$ & $7.17^{d}$ & 5 & $6.51^{d}$ & $6.65^{d}$ & $6.14^{\mathrm{e}}$ & $6.60^{d}$ \\
\hline 30 & $6.55^{d}$ & $6.34^{\mathrm{e}}$ & $6.14^{\mathrm{e}}$ & $6.51^{\mathrm{e}}$ & 6 & $6.00^{\mathrm{e}}$ & $5.95^{\mathrm{e}}$ & 5.74 & $5.93^{\mathrm{e}}$ \\
\hline S.E.M & 0.059 & 0.071 & 0.062 & 0.051 & S.E.M & 0.128 & 0.103 & 0.148 & 0.102 \\
\hline CD at $5 \%$ & 0.171 & 0.027 & 0.184 & 0.157 & CD at $5 \%$ & 0.364 & 0.326 & 0.396 & 0.215 \\
\hline
\end{tabular}

*Means by different superscript as letters (a,b,c,d,e) in a column differ significantly at $5 \%$ level SP(d) - Storage Period (day); C\&A - Colour and Appearance; Cons. -Consistency; Flav-Flavour: OAA - Overall acceptability.

Table 6: Changes in sensory characteristics of the sample B probiotic beverage during storage

from whey and Aloe vera juice was $0.553 \%$ (La). The acidity increased during the refrigerated storage from 0.546 to $0.870 \%$ after 30 days. The increase in acidity was more prominent in case of storage at ambient temperature wherein the acidity reached $1.120 \%$ after 6 days of storage (Table 5). It showed that the titratable acidity values were significantly influenced by the days of storage of whey beverage both at refrigeration and room temperature. Rodas et al. [27] showed that that the titratable acidity values were significantly influenced by the day of storage whey beverage both at refrigerated and room temperature.

\section{Total viable counts of probiotic beverage during storage}

The initial total viable count of the beverage was $3.5 \times 10^{7} \mathrm{cfu} / \mathrm{ml}$ which decreased to $1.3 \times 10^{7}$ at refrigerated storage $\left(4^{\circ} \mathrm{C} \pm 1^{\circ} \mathrm{C}\right)$. Although the viability of Biofidobacterium bifidum (B.p) population decreased, 
Citation: Sasi Kumar R (2015) Development, Quality Evaluation and Shelf Life Studies of Probiotic Beverages using Whey and Aloe vera Juice. J Food Process Technol 6: 486. doi:10.4172/2157-7110.1000486

the viable count of the probiotic beverage did not fall below $10^{7} \mathrm{cfu} /$ $\mathrm{ml}$ (Table 6). During storage at $35^{\circ} \mathrm{C} \pm 1^{\circ} \mathrm{C}$ the total viable count first increased to $8.7 \times 10^{7} \mathrm{cfu} / \mathrm{ml}$ (in $2^{\text {nd }}$ day) and then gradually declined to $2.3 \times 10^{7} \mathrm{cfu} / \mathrm{ml}$ after 6 days. Our results are in confirmation with other researchers [28] who also reported a decline in total viable count of Lactobacillus acidophilus, Lactobacillus reuteri and Biofidobacterium bifidum of whey based probiotic beverage stored at $4^{\circ} \mathrm{C} \pm 1^{\circ} \mathrm{C}$. Wang et al. [28], studied the survival Biofidobacterium bifidum (B.p) of in commercial yoghurt during refrigerated storage.

\section{Conclusion}

Above study has revealed satisfactorily good quality probiotic beverage with therapeutic value prepared by using a 70:30 blend of whey and Aloe vera juice inoculated with 1 percent inoculum of Biofidobacterium bifidum (B.p) with a shelf life of 30 days at $4^{\circ} \mathrm{C} \pm 1^{\circ} \mathrm{C}$ and 6 days at $35^{\circ} \mathrm{C} \pm 1^{\circ} \mathrm{C}$.

\section{References}

1. Yalcin S, Wade VN, Hassan Md N (1994) Utilization of chhana whey for the manufacture of soft drinks. J Food 19: 351-355.

2. Horton BS (1995) Whey processing and utilization. Information Bulletin -International Dairy Federation 308: 2-6.

3. Smithers GW (2008) Whey and whey proteins - From gutter-to-gold. Int Dairy J 18: 695-704.

4. Shukla FC, Sharma A, Singh B (2004) Studies on the preparation of fruit beverages using whey and buttermilk. J Food Sci Technol 41: 102-104.

5. Singh S, Singh AK, Patil GR (2005) Whey utilization for health beverage. Indian Food Industry 21: 38-41.

6. Yadav RB, Yadav BS, Kalia N (2010) Development and storage studies on whey-based banana herbal (Menthaarvensis) beverage. Am J Food Technol 5: 121-129.

7. Katz F (2001) Active cultures add function to yogurt and other foods. Food Technol 55: 46-49.

8. Devi, Radha Y, Rao YM (2005) Cosmeceutical applications of aloe gel. Natural Product Radiance 4: 322-327.

9. Eshun K, He Q (2004) Aloe vera: a valuable ingredient for the food, pharmaceutical and cosmetic industries-A review. Crit Rev Food Sci Nutr 44: 91-96.

10. Salminen S, Ouwehand A, Benno Y, Lee YK (1999) Probiotics: how should they be defined? Trends Food Sci Tech 10: 107-110.

11. Saarela M, Lähteenmäki L, Crittenden R, Salminen S, Mattila-Sandholm T (2002) Gut bacteria and health foods-The European perspective. Int J Food Microbiol 78: 99-117.
12. Alizadeh A, Ehsani MR (2008) Probiotic survival in yogurt made from ultrafiltered skim milk during refrigeration storage. Research Journal of Biological Sciences 3: 1163-1165.

13. Vinderola CG, Bailo N, Reinheimer JA (2000) Survival of probiotic microflora in argentinian yoghurts during refrigerated storage. Food Res Int 33:97-102.

14. Heller JK (2001) Probiotic bacteria in fermented foods: Product characteristics and starter organisms.Am J Clin Nutr 73: 374-379.

15. Sakhale BK, Pawar VN, Ranveer RC (2012) Studies on the development and storage of whey based RTS beverage from Mango v. Kesar. J Food Process Technol 3: 1000148

16. Shah NP (2000) Probiotic bacteria: Selective enumeration and survival in dairy foods. J Dairy Sci 83: 894-907.

17. Sasikumar R, Ray RC, Paul PK, Suresh CP (2013) Development and storage studies of therapeutic ready to serve (RTS) made from blend of Aloe vera Aonla and ginger juice. J Food Process Technol 4: 232-237.

18. Ramachandra CT, Srinivasa PR (2008) Processing of Aloe Vera leaf gel: A review. American Journal of Agricultural and Biological Sciences 3: 502-510.

19. Williams S (1984) Official methods of analysis. Association of Official Analytical Chemists, (14thedn), Washington DC, USA.

20. APHA, Vanderzant C (1992) Splits Toesser, ed. compendium of methods for microbiological examination of foods. Washington. Amer Public Health Assoc 14: 919-927.

21. Elliker PR, Anderson AW, Hennenson G (1956) An agar culture medium for lactic acid Streptococci and Lactobacilli. J Dairy Sci 39: 1611-1612.

22. Snedecor GW, Cochron WG (1989) Statistical methods. (6thEdn), Oxford and IBH Publishing Co, India.

23. Larmond E (1977) Laboratory methods for sensory evaluation of foods. Department of Agriculture. Ottawa, Canada.

24. Divya, Kumari A (2009) Effect of different temperatures, timings and storage periods on physico-chemical and nutritional characteristics of whey guava beverage. World J Dairy Food Sci 4: 118-122.

25. Shah NP Lankaputhra WEV, Britz ML, Kyle WAS (1995) Survival of Lactobacillus acidophilus and Bifido bacteriumbifidum in commercial yoghurt during refrigeration.

26. Rodas BA, Angulo JO, Jde la Cruz, Garcia HS (2002) Preparation of probiotic buttermilk with Lactobacillus reuteri. Milchwissenschaft 57: 26-28.

27. Heller JK (2001) Probiotic bacteria in fermented foods: Product characteristics and starter organisms. Am J Clin Nutr 73: 374-379.

28. Wang YC, Yu RC, Chou CC (2002) Growth and survival of bifidobacteria and lactic acid bacteria during the fermentation and storage of cultured soymilk drinks. Food Microbiol 19: 501-508. 